\title{
An Analysis of Teacher's Corrective Feedback and Learners' Uptake in Dialogue Journal
}

\author{
Pipo Nuramirah \\ STKIP Pasundan, Cimahi, Indonesia \\ pipo.nuramirah@gmail.com
}

\begin{abstract}
The aim of the study was to investigate types of corrective feedback the teacher provided in dialogue journal. A total of 20 learners taking Writing 2 Course were classified by English proficiency level into two groups. They were Elementary and Intermediate. The qualitative method was largely employed to understand the phenomenon, and some quantification of data was also used to describe the numbers and percentages of the learners' errors and the provided corrective feedback. The findings showed that the teacher applied explicit, elicitation, metalinguistic, and clarification corrective feedback (CF) to help the learners correct their errors in dialogue journal writings. Explicit and metalinguistic CF was the most frequently used CF subsequently, but explicit was a corrective feedback type that led to the most amount of learners' uptake. Based on the findings, it can be concluded that explicit CF was effective and successful to generate learners' uptake. However, this result contradicts several studies which reported that explicit CF was rather ineffective in generating learners' uptake.
\end{abstract}

Keywords: Corrective Feedback, Uptake, Dialogue Journal

\section{INTRODUCTION}

Writing has often been considered as the most difficult aspect of learning a foreign language and therefore demands a great deal of practice. There are three difficulties in writing; psychological, linguistic, and cognitive difficulties. These could be the reasons why the majority of students dislike writing (Datzman, 2010). Difficulties in writing for English Foreign Language (EFL) learners often lead them to make errors. In language learning, learners' errors are caused by several different processes that include: borrowing patterns from the mother tongue; extending patterns from the target language; and expressing meanings using the words and grammar which are already known. Errors in writing English can be categorized into four categories; grammatical, syntactic, lexical, semantic, and substance.

In most EFL classes, learning emphasis is put on oral competence, speaking, not writing. That is why many EFL learners are not able to write. To help them to be able to write, equal emphasis should be given to writing. It can be in form of giving a lot of exercises in writing. One of the exercises is dialogue journal. One of the leading researchers of dialogue journal applications, Peyton, et al (1984) remarks that using dialogue journal is a useful strategy because dialogue journal is a written conversation in which a student and a teacher communicate regularly and it also presents an opportunity for the teacher to make writing more involved with all students.

Unfortunately, dialogue journal does not let the teacher provide corrective feedback towards errors produced by the learners in their dialogue journal writings. Instead of evaluating errors or assessing learners' writings, the teacher simply provides response to what they have written. Afterwards, the learners reply to respond to the teacher's response or feedback.

Over the past twenty years, studies of language education have given considerable attention to the issue of how to provide feedback to students' writing. Feedback has been shown to play a facilitative role in learning because it provides opportunities for comprehensible input, comprehensible output and feedback on learner attempt. The role of feedback has a place in most theories of Second Language (L2) learning and language pedagogy. In both behaviorist and cognitive theories of L2 learning, feedback is seen as contributing to language learning.

When feedback is used to build relationships with students and targeted to their personality and needs, students are more likely to perceive it as effective. Students are historically and sociologically situated active agents who respond to what they see as valuable and useful and to people they regard as engaging and credible. It means that the way teacher delivers feedback is very important because it can influence students' responses and/or students' uptake. Uptake is defined as a student's utterance that immediately follows the teacher's feedback and that constitutes a reaction in some way to the teacher's intention to draw attention to some aspect of the student's initial utterance (Lyster \& Ranta, 1997), while in this study, uptake is defined as students' responses to corrective feedback in which, in case of an error, students attempt to correct their mistake(s).

In order to further understand the mechanism of corrective feedback and uptake, several relevant terms used in this study need to be introduced. Corrective feedback types applied in this study were the six CF types proposed by Lyster and Ranta (1997). The six types constitute: 1) explicit correction: teachers supply the correct form and clearly indicate that what the students say is incorrect; 2) recast: teacher implicitly reformulates all or part of the student's Utterance; 3) elicitation: teacher directly elicits by asking questions or by pausing to allow students to complete teacher's utterance, or asking students to reformulate their utterance; 4) metalinguistic feedback: to the well-formedness of the student's utterance; 5) clarification request: teacher's request for further information from a student about a previous utterance; 6) repetition: teacher repeats the student's ill-formed utterance, adjusting intonation to highlight the error. Considering this study, the learner's utterance in this 
case can be understood as learner's writing. Meanwhile, uptake in this sense is used as a way of evaluating the effectiveness of feedback types which can be divided into two categories: "repair" and "needs repair" (Lyster \& Ranta, 1997, p. 49).

All in all, this study intends to investigate types of teacher's corrective feedback as well as CF type that leads to the most amount of learners' uptake and learners' uptake applied in both elementary and intermediate learners' dialogue journal writings.

\section{METHOD}

This study investigated types teacher's corrective feedback in learners' dialogue journal writings. To serve the purpose, this study was conducted by using a descriptive method. The aim of descriptive method is to collect factual information that describes existing phenomenon, identifies problems or justifies current conditions and practices, makes comparisons and evaluations, determines what others are doing with similar problems or situations and benefits from their experience in making future plans and decisions.

Since this study was conducted using a descriptive method, the study describes the variables, phenomenon, and facts related to teacher's feedback and learners' uptake in dialogue journal. The participants of the study were an English teacher and EFL learners of STKIP Pasundan Cimahi. The teacher holds a degree in English education and teaches Writing 2 course. The EFL learners were the third semester learners of class A and B who were taking Writing 2 course. The 20 learners from different levels of English proficiency were taken purposively. They were 10 elementary learners and 10 intermediate learners. The intermediate level consists of 7 lower intermediate learners and 3 upper intermediate learners. As third semester EFL learners means that they have basic knowledge in writing in English.

\section{FINDINGS AND DISCUSSION}

The followings are the data obtained in the study:

Table 1. Students' errors in dialogue journal writings

\begin{tabular}{clcc}
\hline No. & \multicolumn{1}{c}{ Error } & $\begin{array}{c}\text { Occurrence } \\
(\Sigma)\end{array}$ & $\begin{array}{c}\text { Percentages } \\
(\mathbf{\%})\end{array}$ \\
\hline 1 & $\begin{array}{l}\text { Grammatical } \\
\text { Error }\end{array}$ & 363 & $68.5 \%$ \\
\hline 2 & Syntactical Error & 13 & $3.5 \%$ \\
\hline 3 & Lexical Error & 34 & $9 \%$ \\
\hline 4 & Semantic Error & 73 & $19 \%$ \\
\hline & Total & $\mathbf{3 8 3}$ & $\mathbf{1 0 0 \%}$ \\
\hline
\end{tabular}

Table 1 shows errors made by the students in their dialogue journal writings. 383 errors were found in the data. They were 263 grammatical errors $(68.5 \%), 13$ syntactical errors $(3.5 \%)$, 34 lexical errors (9\%), and 73 semantic errors (19\%). The findings show that the most frequently made error by students was grammatical error followed by semantic, lexical, and syntactical errors. The percentages of each error category were very significant. It means that grammar is very difficult for the students to master.
Table 2. Distribution of teacher's feedback types towards learners' errors

\begin{tabular}{|c|c|c|c|c|}
\hline No. & Error-I & edback & $\begin{array}{c}\text { Occurrence } \\
(\Sigma)\end{array}$ & $\begin{array}{c}\text { Percentages } \\
(\%)\end{array}$ \\
\hline \multirow{6}{*}{1} & \multirow{6}{*}{$\begin{array}{l}\text { Grammatical } \\
\text { Error }\end{array}$} & Explicit & 104 & $27 \%$ \\
\hline & & Recast & - & - \\
\hline & & Elicitation & 3 & $0.8 \%$ \\
\hline & & Metalinguistic & 150 & $39.2 \%$ \\
\hline & & Clarification & 5 & $1.3 \%$ \\
\hline & & Repetition & - & - \\
\hline \multirow{6}{*}{2} & \multirow{6}{*}{$\begin{array}{l}\text { Syntactical } \\
\text { Error }\end{array}$} & Explicit & 1 & $0.3 \%$ \\
\hline & & Recast & - & - \\
\hline & & Elicitation & - & - \\
\hline & & Metalinguistic & 12 & $3.1 \%$ \\
\hline & & Clarification & - & - \\
\hline & & Repetition & - & - \\
\hline \multirow{6}{*}{3} & \multirow{6}{*}{ Lexical Error } & Explicit & 26 & $7 \%$ \\
\hline & & Recast & - & - \\
\hline & & Elicitation & 1 & $0.3 \%$ \\
\hline & & Metalinguistic & 4 & $1.1 \%$ \\
\hline & & Clarification & 4 & $1.1 \%$ \\
\hline & & Repetition & - & - \\
\hline \multirow{6}{*}{4} & \multirow{6}{*}{ Semantic Error } & Explicit & 58 & $15 \%$ \\
\hline & & Recast & - & - \\
\hline & & Elicitation & - & - \\
\hline & & Metalinguistic & 13 & $3.5 \%$ \\
\hline & & Clarification & 1 & $0.3 \%$ \\
\hline & & Repetition & - & - \\
\hline \multicolumn{3}{|c|}{ Total } & 383 & $100 \%$ \\
\hline
\end{tabular}

Table 2 presents the distribution of corrective feedback types provided by the teacher towards learners' errors in dialogue journal writings. In the data, there were 383 errors made by the learners of both elementary and intermediate level. Those errors were corrected by explicit, metalinguistic, clarification and elicitation with $49.3 \%, 46.9 \%, 2.7 \%$, and $1.1 \%$ subsequently.

Table 3. Connection between teacher's corrective feedback and learners' uptake

\begin{tabular}{|c|c|c|c|c|c|}
\hline \multirow[b]{2}{*}{ No. } & \multirow[b]{2}{*}{$\begin{array}{c}\text { Types of } \\
\text { Corrective } \\
\text { Feedback }\end{array}$} & \multirow{2}{*}{$\begin{array}{c}\text { Total of } \\
\text { Occurrence } \\
(\Sigma)(\%)\end{array}$} & \multicolumn{2}{|c|}{ Learners' Uptake } & \multirow{2}{*}{$\begin{array}{c}\text { Total of } \\
\text { Uptake } \\
(\%)\end{array}$} \\
\hline & & & $\begin{array}{c}\text { Repair } \\
(\Sigma) \\
(\%)\end{array}$ & $\begin{array}{l}\text { Needs- } \\
\text { repair } \\
(\Sigma)(\%)\end{array}$ & \\
\hline 1 & Explicit & $\begin{array}{c}189 \\
(100 \%)\end{array}$ & $\begin{array}{c}157 \\
(83 \%) \\
\end{array}$ & $\begin{array}{c}32 \\
(17 \%)\end{array}$ & $54 \%$ \\
\hline 2 & Recast & - & - & - & - \\
\hline 3 & Elicitation & $\begin{array}{c}4 \\
(100 \%)\end{array}$ & $\begin{array}{c}2 \% \\
(100 \%)\end{array}$ & $\begin{array}{c}2 \% \\
(100 \%)\end{array}$ & $0.7 \%$ \\
\hline 4 & Metalinguistic & $\begin{array}{c}180 \\
(100 \%)\end{array}$ & $\begin{array}{c}123 \\
(68 \%) \\
\end{array}$ & $\begin{array}{c}57 \\
(32 \%) \\
\end{array}$ & $42.7 \%$ \\
\hline 5 & Clarification & $\begin{array}{c}10 \\
(100 \%)\end{array}$ & $\begin{array}{c}6 \\
(60 \%) \\
\end{array}$ & $\begin{array}{c}4 \\
(40 \%) \\
\end{array}$ & $2.1 \%$ \\
\hline 6 & Repetition & - & - & - & - \\
\hline & Total & $\begin{array}{c}383 \\
(100 \%)\end{array}$ & $\begin{array}{c}288 \\
(75 \%)\end{array}$ & $\begin{array}{c}94 \\
(25 \%)\end{array}$ & $(100 \%)$ \\
\hline
\end{tabular}

Of all teacher's corrective feedback, it is shown that $75.4 \%$ (288 CF) resulted in repair leading to the learners' uptake, and $24.6 \%$ (94 CF) resulted in needs-repair meaning no learners' uptake. Explicit was the most frequently used CF that led to amount of learners' uptake. The findings of the present study were different from the previous study. The previous study conducted by Sheen (2004) found that recast was the most frequently used corrective feedback by teacher that led to the most amount of uptake. 
The findings of the study revealed teacher's corrective feedback types given differently to learners' errors in dialogue journal writings as well as the variety of learners' uptake. Based on the findings, there were various errors found in dialogue journal writings made by both elementary and intermediate learners. To correct the errors, the teacher provided different types of corrective feedback. Those different types of CF were given based on the learners English proficiency level. In dialogue journal writings of elementary learners, the most frequently used corrective feedback was explicit CF. This type of CF allows the teacher to supply the correct form and to clearly indicate whether what the students say or write is incorrect (Lyster \& Ranta, 1997). The most frequently used CF, explicit CF was also the most amount of uptake that the elementary learners made in responding to the teacher's CF. It seemed that explicit CF was easier for them to understand and follow in correcting their errors. It means that explicit CF was helpful for the students to correct their errors. In dialogue journal writings of intermediate learners, the most frequently used corrective feedback was metalinguistic CF. This type of $\mathrm{CF}$ allows the teacher to make the students aware of the well-formedness of their utterance or writing. In spite of the fact that metalinguistic CF was the most frequently used $\mathrm{CF}$, the most amount of uptake that the intermediate students made was explicit CF. This result was in line with the finding in the elementary learners' dialogue journal writings.

All in all, the present study discovered that the way the teacher provided corrective feedbacks for both elementary and intermediate learners was different. She provided CF based on the students level of English proficiency. Although both elementary and intermediate learners preferred explicit $\mathrm{CF}$ to other types of $\mathrm{CF}$, their ability to respond to the provided $\mathrm{CF}$ was not the same. It can be seen from the way they responded to the $\mathrm{CF}$ types provided by the teacher. The findings showed that it was quite hard for the elementary learners to respond to other types of $\mathrm{CF}$, especially metalinguistic CF. Meanwhile, for the intermediate learners, despite the percentage of explicit $\mathrm{CF}$ resulting in uptake was the highest one than the other types, the students could still respond to other types of $\mathrm{CF}$ well. However, explicit $\mathrm{CF}$ became the easiest way for both elementary and intermediate learners to understand and follow in correcting their errors.

\section{CONCLUSION}

This study indicates all of learners' errors, teacher's types of corrective feedback, and learners' uptake in both elementary and intermediate learners' dialogue journal writings. The findings reveal that the most frequently made error by students was grammatical error. It means that grammar is very difficult for the students to master. To help them correct their errors, the teacher applied four types of CF. The CF types were given based on learners' level of English proficiency. Explicit CF was the most frequently used $\mathrm{CF}$ by the teacher to correct the elementary learners' writings. Meanwhile, the most frequently used $\mathrm{CF}$ in intermediate learners' dialogue journal writings was metalinguistic CF. However, both elementary and intermediate learners preferred explicit CF to other types of CF. It was proven by the result of explicit $\mathrm{CF}$ that led to the most amount of uptake. It means that explicit CF became the easiest way for both elementary and intermediate learners to understand and follow in correcting their errors. Based on the findings, it can be concluded that explicit $\mathrm{CF}$ was effective and successful to generate learners' uptake (Lee, 1997; Fathman \& Whalley, 1990). This result contradicts several studies (Kepner, 1991; Polio, Fleck, \& Leder, 1998; Robb, Ross, \& Shortreed, 1986; Semke, 1984; Sheppard, 1992; Surakka, 2007) which reported that explicit $\mathrm{CF}$ was rather ineffective in generating learner uptake.

\section{REFERENCES}

Datzman, K. (2010). Dialogue Journals With English Language Learners: Using Dialogue Journals to Improve Writing for English Language Learners. The United States: University of Arkansas.

Fathman, A., \& Whalley, E. (1990). Teacher Response to Student Writing: Focus on Form Versus Content. In B. Kroll (Ed.), Second language writing: Research insights for the classroom (pp. 178-190). Cambridge: Cambridge University Press.

Kepner, C. G. (1991). An Experiment in the Relationship of Types of Written Feedback to the Development of Second Language Writing Skills. Modern Language Journal, 75, $305-313$.

Lee, I. (1997). ESL Learners' Performance in Error Correction in Writing: Some Implications for CollegeLevel Teaching. System, 25, 465-477.

Lyster, R. \& Ranta, L. 1997: Corrective Feedback and Learner Uptake: Negotiation of Form in Communicative Classrooms. Studies in Second Language Acquisition 19, 37-66.

Peyton, J. K., Shuy, R., Staton, .J., Reed, L., \& Morroy, R. (1984). Dialogue writing: Analysis of Student-Teacher Interactive Writing in the Learning of English as a Second Language. Washington, DC: Center for Applied Linguistics.

Polio, C., Fleck, N., \& Leder, N. (1998). "If only I had more time', ESL learners' changes in linguistic accuracy on essay revisions. Journal of Second Language Writing, 7, 43-68.

Robb, T., Ross, S., \& Shortreed, I. (1986). Salience of Feedback on Error and its Effect on EFL Writing Quality. TESOL Quarterly, 20, 83-93.

Semke, H. (1984). The Effects of the Red Pen. Foreign Language Annals, 17, 195202.

Sheen, YoungHee. 2004. Corrective Feedback and Learner Uptake in Communicative Classrooms across Instructional Settings. Columbia: Columbia University.

Sheppard, K. (1992). Two Feedback Types: Do They Make a Difference? RELC Journal, 23, 103-110.

Surakka, K. (2007). Corrective Feedback and Learner Uptake. Kesakuu: UNIVERSITY OF JYVÄSKYLÄ. 